\title{
PENERAPAN MODEL PBL DALAM PEMBELAJARAN DARING UNTUK MENINGKATKAN KREATIVITAS BELAJAR SISWA KELAS IV TEMA 7
}

\author{
Muhamad Bisri*, Henny Dewi Koeswanti, Tri Sadono \\ Program Studi Pendidikan Profesi Guru, FKIP, Universitas Kristen Satya Wacana \\ *Corresponding Author: 952020513@student.uksw.edu
}

\section{Article History}

Received : April 05 ${ }^{\text {th }}, 2021$

Revised : April 10 ${ }^{\text {th }}, 2021$

Accepted : May 05 ${ }^{\text {th }}, 2021$

Published : May $09^{\text {th }}, 2021$

\begin{abstract}
Abstrak: Penelitian ini dilatarbelakangi rendahnya kreativitas belajar siswa di kelas IV SDN Karang Blora. Dimana berdasarkan hasil observasi awal sebanyak $68 \%$ siswa memiliki kreativitas belajar rendah. Tujuan penelitian ini yaitu untuk meningkatan kreativitas belajar siswa melalui pembelajaran dengan model PBL, dan bagaimana cara pelaksanaan pembelajaran model PBL dalam meningkatkan kreativitas belajar siswa. Model pembelajaran PBL adalah model pembelajaran konstruktivisme yang menuntut peran aktif siswa dalam memahami pengetahuan dan mengembangkan penalaran mereka. Jenis penelitian ini yaitu Penelitian Tindakan Kelas (PTK) dengan model dari Kemmis dan Mc.Taggart yang setiap siklusnya terdiri dari (1) perencanaan, (2) pelaksanaan tindakan dan observasi, dan (3) refleksi. Penelitian ini terdiri dari dua siklus yang setiap siklusnya terdiri dari dua pertemuan. Subjek penelitian yaitu siswa kelas IV SDN Karang Kabupaten Blora, dengan jumlah 16 orang, 8 orang laki-laki dan 8 orang perempuan. Teknik pengumpulan data dilaksanakan dengan observasi dan tes melalui LKPD, sedangkan teknik analisis data menggunakan analisis deskriptif. Dari hasil penelitian diperoleh, kreativitas belajar siswa kelas IV tema 7 subtema 1 pembelajaran 2 dan 3 SDN Karang meningkat dengan menggunakan model PBL terlihat dari aspek psikomotoriknya yaitu: pada tes awal 32\%, hasil siklus I meningkat menjadi $50 \%$, dan mengalami.peningkatan pada tes siklus II menjadi $87 \%$. Jadi berdasakan tindakan pada siklus 1 dan siklus 2 terjadi peningkatan presentase pencapaian kreativitas belajar siswa melalui penerapan model PBL. Dengan demikian model PBL ini cocok digunakan dalam pembelajaran untuk meningkatkan kreativitas belajar siswa.
\end{abstract}

Kata kunci: Kreativitas, PBL

\section{PENDAHULUAN}

Kurikulum 2013 dikembangkan sebagai upaya peningkatan kreativitas belajar melalui pembelajaran yang inovatif. (Juharyanto et al., 2018) pendekatan pembelajaran yang digunakan di kurikulum 2013 adalah tematik terpadu dan saintifik, kedua pendekatan pembelajaran tersebut perlu dipadukan dengan model-model pembelajaran yang sesuai dengan kedua pendekatan tersebut, diantaranya adalah discovery learning, problem based learning, dan projec based learning. Problem based learning (PBL) adalah model pembelajaran konstruktivisme yang menuntut peran aktif siswa dalam memahami pengetahuan dan mengembangkan penalaran mereka. Pada model PBL (Esema et al., 2012) menyatakan, "Siswa dituntut untuk bisa berpikir kritis dalam memecahkan masalah dan diharapkan dapat mengaplikasikannya dalam kehidupan mereka sehari-hari". Model pembelajaran Problem
Based Learning membantu peserta didik dalam mengembangkan kecakapan memecahkan masalah, meningkatkan pemahaman dan pengetahuan, serta keaktifan dalam mendapatkan pengetahuan (Koeswanti, 2018).

Model pembelajaran PBL didesain untuk meningkatkan kreativitas belajar sehingga tujuan pendidikan dapat tercapai dengan baik. Undang-undang nomor 20 tahun 2003 tentang system pendidikan nasional, pasal 3 menyebutkan tujuan pendidikan yaitu mengembangkan potensi peserta didik agar menjadi manusia yang beriman dan bertakwa kepada. Tuhan Yang Maha Esa, berakhlak mulia, sehat, berilmu, cakap, kreatif, mandiri, dan menjadi warga negara yang demokratis serta bertanggung jawab. Salah satu tujuan pendidikan menyebutkan menjadikan manusia yang kreatif. Kreatif yang dimaksud adalah kreativitas siswa dalam belajar.

Kreativitas belajar merupakan kemampuan yang harus dimiliki oleh siswa saat 
melaksanakan pembelajaran. Kreativitas belajar adalah kemampuan yang mencerminkan kelancaran, keluwesan, orisinalitas dalam berfikir, serta kemampuan untuk mengelaborasi (mengembangkan, memperkaya, memperinci) suatu gagasan dan kemampuan, memberikan penilaian terhadap suatu obyek atau situasi (Rahmawati, 2017). Kreativitas belajar penting untuk ditanamkan pada siswa sejak di bangku sekolah dasar. Siswa yang memiliki kemampuan kreativitas belajar dapat menyelesaikan masalah baik di sekolah, rumah, atau masyarakat.

Ciri-ciri kreativitas dapat dibedakan menjadi dua, yaitu ciri atitude dan nonatitude. Dalam penelitian ini, hanya menggunakan ciri attitude. (Munandar, 2017) menjelaskan ciriciri kreativitas belajar dalam bentuk atitude yang mana peneliti gunakan sebagai indikator kreativitas belajar adalah:

1. Ketrampilan berpikir luwes yaitu menghasilkan gagasan, jawaban atau pertanyaan bervariasi; dapat melihat suatu masalah dari sudut pandang yang berbedabeda; mencari banyak alternatif, mampu mengubah cara pendekatan atau pemikiran.

2. Ketrampilan berpikir lancar yaitu mencetuskan banyak gagasan, jawaban, penyelesaian masalah atau pertanyaan; memberikan banyak cara atau saran untuk melakukan lebih dari satu jawaban.

3. Ketrampilan berpikir rasional yaitu mampu melahirkan ungkapan yang baru dan unik; memikirkan cara yang tidak lazim untuk mengungkapakan diri, mampu membuat kombinasi yang tidak lazim dari unsurunsur.

4. Ketrampilan mengelaborasi yaitu mampu memperkarya dan mengembangkan suatu gagasan atau produk; memerinci detil-detil suatu obyek, gagasan.atau situasi sehingga lebih menarik.

5. Ketrampilan menilai yaitu menentukan patokan penilaian sendiri dan.menentukan apakah suatu pertanyaan benar, mampu mengambil keputusan terhadap situasi yang terbuka, tidak hanya mencetuskan ide tetapi juga melaksanakanya.

Pembelajaran dengan model PBL dapat meningkatkan kreativitas belajar siswa, hal ini didukung dengan hasil penelitian yang dilakukan oleh (Wahyuni, 2014) tentang peningkatan kreativitas belajar melalui PBL yang menunjukkan kenaikan persentase kreativitas siswa sebesar 23,09\% di siklus 1 dan $27,31 \%$ untuk siklus 2 Penelitian lain yang sejenis, yaitu oleh (Damanik, 2016) bahwa terdapat peningkatan kreativitas belajar melalui pembelajaran PBL dari siklus 1 sebesar 54,45\% meningkat di siklus 2 sebesar 85,23\%. Pembelajaran PBL selain meningkatkan kreativitas belajar, juga dapat meningkatkan hasil belajar siswa. Sesuai penelitian yang dilakukan oleh (Wardani, 2011) tentang upaya peningkatan kreativitas siswa yang hasilnya terdapat peningkatan ketuntasan belajar siswa di siklus 1 sebesar $61,12 \%$ dari 18 siswa menjadi $88,89 \%$ dari 18 siswa di siklus 2 .

Berdasarkan hasil pengamatan dalam pembelajaran tematik terpadu pada siswa kelas IV SDN Karang semester I tahun pelajaran 2020/2021 ditemukan fenomena antara lain dalam pembelajaran tematik terpadu belum pernah.dilakukan pembelajaran dengan desain PBL yang menuntut peran siswa untuk mengembangkan pengetahuanya sendiri dengan cara menyelesaikan masalah nyata. Perserta didik dalam pembelajaran belum aktif karena pembelajaran masih terpusat pada guru (teacher center). Pembelajaran yang dilakukan oleh guru adalah pembelajaran konvensional. Metode yang digunakan dalam pembelajaran konvensional adalah ceramah. Pembelajaran konvensional yang monoton membuat siswa menjadi pasif dalam mengikuti pembelajaran. Kegiatan pembelajaran daring siswa kelas IV hanya melalui media aplikasi whatsapp group dengan cara guru memberikan tugas-tugas kepada peserta didik saja. Hal ini menyebabkan peserta didik kurang memahami materi yang diajarkan dan menimbulkan kurangnya kreativitas belajar siswa. Selain itu, terlihat pula belum ada penilaian terhadap kreativitas belajar siswa, sehingga kemampuan kreativitas belajar siswa dalam pembelajaran tematik terpadu belum nampak. Dalam.penilaian kreativitas belajar nampak pada kegiatan siswa dalam mengeluarkan pendapat, menjawab pertanyaan, membuat pertanyaan, menyampaikan hasil kerja, dan menilai hasil pekerjaan. Hasil pengamatan pembelajaran tematik terpadu pada siswa kelas IV SDN Karang semester 2 tahun pelajaran 2020/2021 sebanyak 68\% dari jumlah 16 siswa memiliki kreativitas belajar rendah.

Berangkat dari masalah pembelajaran siswa kelas IV SDN Karang semester I tahun pelajaran 2020/2021 maka perlu adanya peningkatan kreativitas belajar untuk diupayakan melalui pembelajaran model PBL. Selain itu berdasarkan penelitian yang relevan bahwa model pembelajaran PBL mampu 
meningkatkan kreativitas belajar siswa, sehingga peneliti memilih model PBL dalam kegiatan penelitian. Hal tersebut sesuai dengan tujuan pada penelitian ini yaitu untuk mengetahui apakah peningkatan kreativitas belajar siswa dapat diupayakan melalui pembelajaran dengan model PBL, dan untuk mengetahui bagaimanakah langkah-langkah pembelajaran PBL yang dapat meningkatkan kreativitas belajar siswa.

\section{METODE}

Penelitian ini dilaksanakan di SDN Karang, kecamatan Bogorejo Kabupaten Blora dimana proses pembelajarannya dilakukaan melalui aplikasi Google meet. Penelitian dilaksanakan pada semester 2 tahun pelajaran $2020 / 2021$. Subyek penelitian ini adalah siswa kelas IV sebanyak 16 siswa, yang terdiri dari 8 siswa laki-laki dan 8 siswa perempuan. Teknik pengumpulan data yang digunakan dalam penelitian ini adalah tes melalui LKPD dan observasi. Menurut (Arikunto, 2013) observasi adalah suatu teknik yang dilakukan dengan cara mengadakan pengamatan secara teliti serta mencatat secara sistematis.

Penerapan model PBL pada penelitian ini diaplikasikan dalam kegiatan pembelajaran tema 7 Indahnya Keragaman di Negeriku subtema 2 Indahnya Keragaman Budaya Negeriku dan subtema 3 Indahnya Persatuan dan Kesatuan Negriku pembelajaran ke-1, siswa kelas IV SDN Karang semester 2 tahun pelajaran 2020/2021. Setiap pembelajaran pada subtema 2 dan 3 terdapat 2 muatan pembelajaran, Bahasa Indonesia dan IPA. Dalam penelitian ini, peneliti bekerja sama dengan guru kelas 4 SDN Karang. Variabel penelitian terdiri dari variable bebas yaitu pembelajaran daring dengan model Problem Based Learning (PBL) dan variabel terikatnya adalah kreativitas belajar peserta didik.

Jenis penelitian ini adalah Penelitian Tindakan Kelas (PTK). Model PTK yang akan digunakan dalam penelitian ini adalah menggunakan model spiral, yang..dikemukakan oleh (Kemmis, S. \& Mc.Taggart, 1988) Prosedur penelitian ini menggunakan dua siklus, setiap siklus terdiri dari dua pertemuan yang masingmasing siklus terdiri dari tiga langkah, yaitu: 1) perencanaan, 2) pelaksanaan tindakan dan observasi, 3) refleksi.

Uji validasi instrumen berupa indikator kreativitas belajar pada penelitian ini menggunakan instrument baku yang telah diujicobakan oleh (Waluyo, 2019). Validitas bertujuan untuk menguji kelayakan dan ketepatan setiap item pernyataan dalam rubrik kreativitas belajar, sehingga dapat digunakan alat pengumpul data. Validasi adalah proses kegiatan untuk menilai keefektifan instrumen yang telah dibuat kepada para pakar atau ahli atau sudah memiliki pengalaman untuk menilai instrumen yang dibuat. Dimana hasil uji validasi oleh pakar pada penelitian ini yaitu instrumen layak digunakan untuk mengambil data penelitian dengan revisi sesuai saran dari pakar.

Indikator keberhasilan PTK ini yaitu meningkatnya kreativitas belajar melalui PBL tema 7 Indahnya Keragaman di Negeriku, subtema 2 Indahnya Keragaman Budaya Negeriku dan subtema 3 Indahnya Persatuan dan Kesatuan Negriku, pembelajaran ke 1 siswa kelas IV SDN Karang semester 2 tahun pelajaran 2020/2021. Di mana tingkat kreativitas dikatakan berhasil jika telah mencapai $\geq 80 \%$ dari jumlah seluruh siswa. Teknik analisis data yang digunakan dalam penelitian ini adalah teknik analisis deskriptif dengan menggunakan persentase yaitu membandingkan kreativitas belajar siswa berdasarkan indikator keberhasilan antara siklus I dan siklus II.

\section{HASIL DAN PEMBAHASAN}

\section{Pertemuan siklus 1}

Desain kegiatan pembelajaran PBL siklus 1 terdiri 3 kegiatan, yaitu 1) kegiatan pendahuluan, 2) kegiatan inti dan 3) kegiatan penutup. 3 kegitan seperti ini sesuai dengan penelitian yang dilakukan oleh (Rahmadani \& Anugraheni, 2017) kegiatan pelaksanaan pembelajaran teridiri dari pendahuluan, inti dan penutup. Langkah pembelajaran PBL siklus 1 terdapat 10 langkah pembelajaran. 10 langkah pembelajaran tersebut, yaitu: 1) mengungkapkan gagasan macam-macam masalah keragaman budaya, 2) mengungkapkan faktor-faktor penyebab masalah keragaman budaya, 3) menjawab pertanyaan tentang materi masalah keragaman budaya, 4) memecahkan masalah keragaman budaya secara sistematis, 5) membuat pertanyaan tentang teks masalah keragaman budaya, 6) menunjukkan kelemahan penggunaan gaya listrik, 7) menunjukkan kelebihan penggunaan gaya listrik. 8) mendemonstrasikan gaya pada peralatan rumah tangga, 9) meyusun laporan manfaat gaya listrik dalam kehidupan sehari-hari secara sistematis, 10) menyampaikan 
manfaat gaya listrik dalam kehidupan sehari-hari. Hasil pengolahan kreativitas belajar siklus 1 secara rinci disajikan dalam diagram 1 distribusi frekuensi kreativitas belajar sebagai berikut.

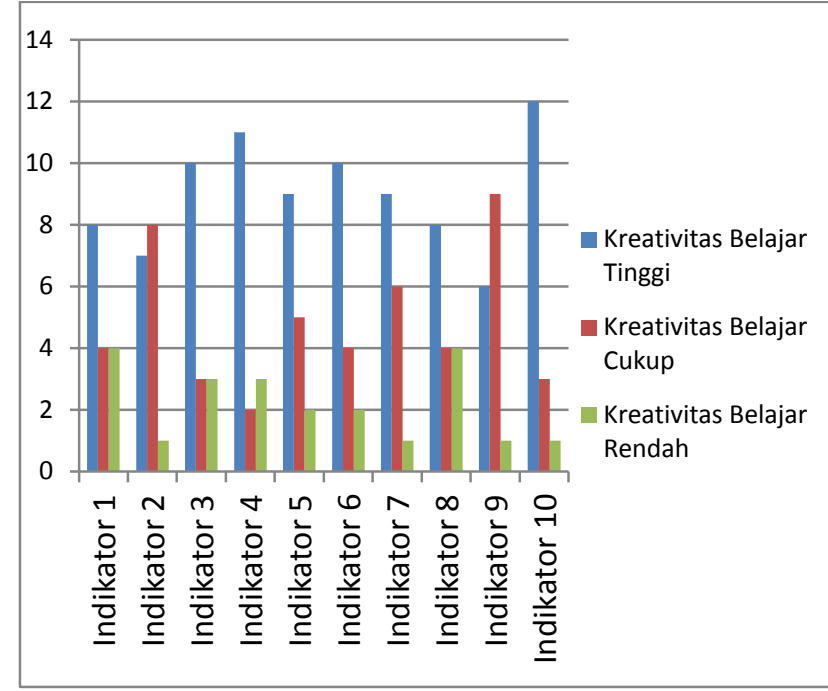

\section{Gambar 1 \\ Diagram Distribusi Frekuensi Kreativitas Belajar Siklus 1}

Pengukuran kreativita belajar siswa dibagi menjadi 3 klasifikasi, yaitu: kreativitas belajar tinggi dengan rentang nilai $\geq 3$. Kreativitas belajar siswa cukup dengan rentang nilai 2-2,9 dan kreativitas belajar rendah dengan nilai < 2 (Rudyanto, 2016). Hasil pengolahan kreativitas belajar siklus 1 secara rinci disajikan dalam tabel 1 distribusi frekuensi kreativitas belajar sebagai berikut.

Tabel 1 Distribusi Frekuensi Kreativitas Belajar Berdasarkan Klasifikasi Siklus 1

\begin{tabular}{|c|c|c|c|c|}
\hline No. & $\begin{array}{l}\text { Rentang } \\
\text { Skor }\end{array}$ & $\begin{array}{l}\text { Klasifikasi } \\
\text { Kreativitas }\end{array}$ & $\begin{array}{c}\text { Freku } \\
\text {-ensi }\end{array}$ & $\begin{array}{c}\text { Persentase } \\
(\%)\end{array}$ \\
\hline 1. & $\geq 3$ & $\begin{array}{l}\text { Kreativitas } \\
\text { Belajar } \\
\text { Tinggi } \\
\text { Kreativitas }\end{array}$ & 8 & $50 \%$ \\
\hline 2. & $2-2,9$ & $\begin{array}{l}\text { Belajar } \\
\text { Cukup } \\
\text { Kreativitas }\end{array}$ & 6 & $37 \%$ \\
\hline 3. & $<2$ & $\begin{array}{l}\text { Belajar } \\
\text { Rendah }\end{array}$ & 2 & $13 \%$ \\
\hline \multicolumn{3}{|c|}{ Jumlah } & 16 & $100 \%$ \\
\hline
\end{tabular}

Sumber: Data Primer

Tabel 1 menunjukkan bahwa hasil keseluruhan kreativitas belajar siswa kelas IV SDN Karang Blora siklus 1. Kreativitas belajar siswa tinggi jika siswa memperoleh rentang skor $\geq 3$, kreativitas belajar cukup jika siswa memperoleh skor 2-2,9, dan kreativitas belajar rendah jika siswa memperoleh skor < 2 (Rudyanto, 2016). Sehingga terlihat siswa yang memiliki kreativitas belajar tinggi atau $\geq 3$ hanya sebanyak 50\% dari 16 siswa.

Berdasarkan hasil kreativitas belajar siklus 1 siswa yang memperoleh skor $\geq 3$ dengan klasifikasi kreativitas belajar tinggi sebanyak 8 siswa (50\% dari jumlah 16 siswa) sehingga kreativitas belajar siswa masih kurang karena belum mencapai indikator keberhasilan $\geq 80 \%$ dari 16 yang masuk klasifikasi kreativitas belajar tinggi, maka selanjutnya perlu diadakan perbaikan dalam siklus 2. Hal ini sesuai dengan penelitian yang dilakukan oleh (Indarwati et al., 2014) yang menjelaskan bahwa jika di siklus 1 tingkat kreativitas siswa pada kategori kreativitas tinggi belum mencapai $80 \%$ maka perlu dilaksanakan siklus 2 .

\section{Pertemuan siklus 2}

Pelaksanaan siklus 2 dengan model pembelajaran PBL di kelas IV SDN Karang semester 2 tahun pelajaran 2020/2021 melalui 3 tahap 3 tahap yang dilakukan dalam pelaksanaan siklus 2 yaitu perencanaan, pelaksanaan tindakan dan observasi, dan refleksi. Pelaksanaan pembelajaran PBL pada siklus 2 terdiri dari 3 kegiatan 3 kegiatan pelaksanaan pembelajaran PBL itu adalah kegiatan pendahuluan, kegiatan inti dan kegiatan penutup. Kegiatan siklus 2 melaksanakan langkah pembelajaran PBL yang terdiri dari 10 langkah, yaitu: 1) mengungkapkan gagasan macam-macam masalah keragaman suku bangsa, 2) mengungkapkan faktor-faktor penyebab masalah suku bangsa, 3) menjawab pertanyaan tentang materi masalah keragaman suku bangsa, 4) memecahkan masalah keragaman suku bangsa secara sistematis, 5) membuat pertanyaan tentang teks masalah keragaman suku bangsa, 6) menunjukkan kelemahan penggunaan alat elektronik, 7) menunjukkan kelebihan penggunaan alat elektronik, 8) mendemonstrasikan gaya magnet pada penggaris dan potongan kertas, 9) meyusun laporan manfaat gaya mqgnet dalam kehidupan sehari-hari secara sistematis, 10) menyampaikan manfaat.gaya magnet dalam kehidupan..seharihari.

Hasil pengolahan kreativitas belajar siklus 2 secara rinci disajikan dalam diagram 2 distribusi frekuensi kreativitas belajar sebagai berikut. 


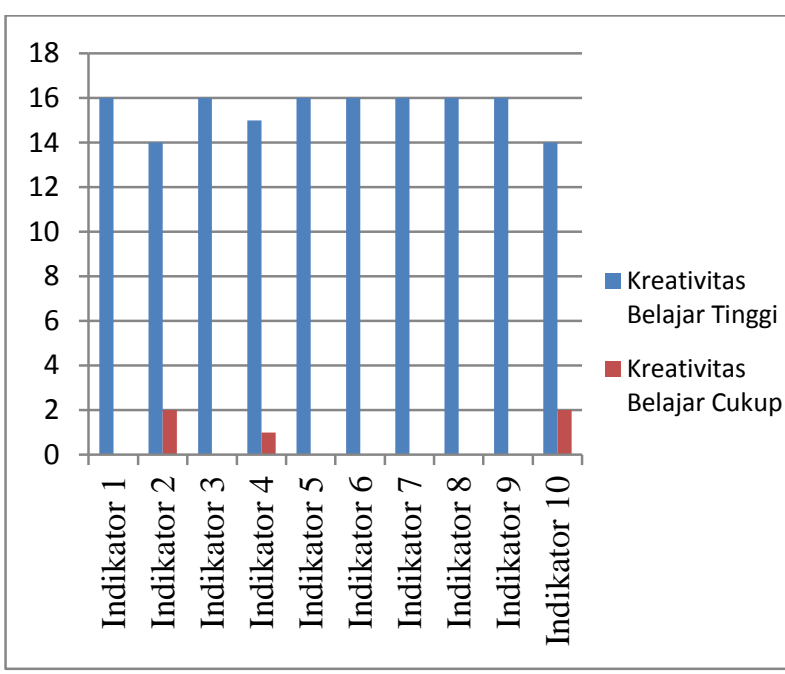

\section{Gambar 2 \\ Diagram Distribusi Frekuensi Kreativitas Belajar Siklus 2}

Hasil pengolahan kreativitas belajar siklus 1 secara rinci disajikan dalam tabel 1 distribusi frekuensi kreativitas belajar sebagai berikut.

Tabel 2 Distribusi Frekuensi Kreativitas Belajar Berdasarkan Klasifikasi Siklus 2

\begin{tabular}{cclcc}
\hline No. & $\begin{array}{c}\text { Rentang } \\
\text { Skor }\end{array}$ & $\begin{array}{l}\text { Klasifikasi } \\
\text { Kreativitas }\end{array}$ & Frekuensi & $\begin{array}{c}\text { Persentase } \\
(\%)\end{array}$ \\
1. & $\geq 3$ & $\begin{array}{l}\text { Belajar } \\
\text { Tinggi }\end{array}$ & 14 & $87 \%$ \\
& & $\begin{array}{l}\text { Kreativitas } \\
\text { Belajar } \\
\text { Cukup }\end{array}$ & 2 & $13 \%$ \\
\multicolumn{2}{c}{$2-2,9$} & 16 & $100 \%$ \\
\hline
\end{tabular}

Sumber: Data Primer

Tabel 2 menunjukkan bahwa hasil keseluruhan kreativitas belajar siswa kelas IV SDN Karang Blora siklus 2. Kreativitas belajar siswa tinggi jika siswa memperoleh rentang nilai $\geq 3$ dan kreativitas belajar cukup jika siswa memperoleh skor 2-2,9. Berdasarkan hasil penelitian kreativitas belajar siklus 2 dimana siswa yang memperoleh skor $\geq 3$ dengan klasifikasi kreativitas belajar tinggi sebanyak 14 siswa (87\% dari jumlah 16 siswa) sehingga dapat dikatakan bahwa penelitian yang dilakukan dinyatakan berhasil, karena mencapai keberhasilan indikator $\geq 80 \%$ dari 16 siswa. Hal ini berarti indikator kinerja sudah tercapai dan tidak perlu diadakan siklus selanjutnya. Hal ini sesuai dengan penelitian yang dilakukan oleh (Indarwati et al., 2014) yang menjelaskan bahwa jika tingkat kreativitas siswa sudah mencapai
$80 \%$ maka tidak perlu dilaksanakan siklus selanjutnya.

\section{KESIMPULAN}

Berdasarkan hasil penelitian dan pembahasan, maka dapat disimpulkan yaitu terdapat peningkatan kreativitas belajar tematik terpadu pada tema 7 siswa kelas 4 SDN Karang, yang diupayakan melalui model pembelajaran PBL yang dilaksanakan dalam dua siklus, yaitu sebanyak $50 \%$ dari seluruh siswa dengan klasifikasi kreativitas belajar tinggi di siklus 1, dan meningkat menjadi $87 \%$ dari seluruh siswa di siklus 2 .

\section{UCAPAN TERIMA KASIH}

Puji Syukur penulis panjatkan kepada kepada Allah SWT yang telah meridhoi dalam penulisan penelitian ini. Kepada kedua orang tua saya Bapak Sujasno dan Ibu Mudrikah yang selalu mendoakan dalam kelancaran penulisan penelitian ini. Dan kepada Dr. Henny Dewi Koeswanti, M.Pd., Tri Sadono, S.Pd., M.Pd, Sukirno, S.Pd.SD dan peserta didik kelas IV SDN Karang yang telah membantu kami sehingga penulis dapat menyelesaikan penelitian ini.

\section{REFERENSI}

Arikunto, S. (2013). Metodologi Penelitian. Rineka Cipta.

Damanik, D. J. (2016). Upaya Peningkatan Kemampuan Berpikir Kreatif Siswa yang Diajarkan dengan Model Problem Based Learning (PBL) di kelas VII SMP Negeri 10 Medan. 66, 37-39.

Esema, D., Susari, E., \& Kurniawan, D. (2012). Problem Based Learning. Satya Widya, 28, 167-173.

Indarwati, D., Wahyudi, W., \& Ratu, N. (2014). Peningkatan Kemampuan Pemecahan Masalah Matematika Melalui Penerapan Problem Based Learning Untuk Siswa Kelas V Sd. Satya Widya, 30(1), 17. https://doi.org/10.24246/j.sw.2014.v30.i1. p17-27

Juharyanto, J., Arifin, I., Bafadal, I., Sobri, A. Y., \& Nurabadi, A. (2018). Dominant Leadership of School Principals in the Implementation of Curriculum 2013 in Religious Based School Indonesia. Asia 
Proceedings of Social Sciences, 2(4), 4751. https://doi.org/10.31580/apss.v2i4.280

Kemmis, S. \& Mc.Taggart, R. (1988). The Action Research Planner. Deakin University Press.

Koeswanti, H. D. (2018). Eksperimen Model Kooperatif Learning dalam Pembelajaran Keterampilan Menulis Karya Ilmiah Mahasiswa Ditinjau Dari Kemampuan Berpikir Logis. Satya Wacana Press.

Munandar, U. (2017). Pengembangan kreativitas anak berbakat. Rineka Cipta.

Rahmadani, N., \& Anugraheni, I. (2017). Peningkatan Aktivitas Belajar Matematika Melalui Pendekatan Problem Based Learning Bagi Siswa Kelas 4 Sd. Scholaria: Jurnal Pendidikan dan Kebudayaan, 7(3), 241.https://doi.org/10.24246/j.scholaria.20 17.v7.i3.p241-250

Rahmawati, R. K. (2017). Pengembangan Perangkat Pembelajaran Dengan Model Contextual Teaching Learning Untuk Meningkatkan Keterampilan Berfikir Kreatif Siswa Kelas V Di Sekolah Dasar. Jurnal Review Pendidikan Dasar: Jurnal Kajian Pendidikan dan Hasil Penelitian, 3(3),534.https://doi.org/10.26740/jrpd.v3n

\section{3.p534-546}

Rudyanto, H. E. (2016). Pengembangan Kreativitas Siswa Sekolah Dasar Melalui Pembelajaran Matematika Open-Ended. Premiere Educandum: Jurnal Pendidikan Dasar dan Pembelajaran, 3(02), 184-192. https://doi.org/10.25273/pe.v3i02.275

Wahyuni, S. (2014). Peningkatan Keaktifan dan Hasil Belajar IPS Melalui Model Group Investigation (GI) Pada Siswa Kelas VI SDN Bandung, Wonosegoro. Scholaria, 4, 97-106.

Waluyo, A. (2019). Upaya Peningkatan Kreativitas Belajar Dalam Pembelajaran Tematik Terpadu Melalui PBL-GI Kelas IV SD. Jurnal basicedu, 3(1), 208-213.

Wardani, N. S. (2011). Upaya Meningkatkan Kreativitas Siswa dalam Pembelajaran IPS SD Melalui Diskusi Kelompok. Widya Sari, 13(1), 1-20. 